\title{
Új módszertani lehetőségek és ezek alkalmazása a hormonális rendszer daganatainak genetikai kivizsgálásában
}

\author{
Patócs Attila dr. ${ }^{1,2,3}$. Likó István dr. ${ }^{1}$ - Butz Henriett dr. ${ }^{4}$ \\ Baghy Kornélia dr. ${ }^{2,5}$. Rácz Károly dr. ${ }^{2,4}$ \\ ${ }^{1}$ Magyar Tudományos Akadémia-Semmelweis Egyetem, „Lendület” Örökletes Endokrin Daganatok \\ Kutatócsoport, Budapest \\ ${ }^{2}$ Bionikai Innovációs Központ Nonprofit Kft., Budapest \\ ${ }^{3}$ Semmelweis Egyetem, Általános Orvostudományi Kar, Laboratóriumi Medicina Intézet, Budapest \\ ${ }^{4}$ Magyar Tudományos Akadémia-Semmelweis Egyetem, Molekuláris Medicina Kutatócsoport, Budapest \\ ${ }^{5}$ Semmelweis Egyetem, Általános Orvostudományi Kar, I. Patológiai és Kísérleti Rákkutató Intézet, Budapest
}

\begin{abstract}
Az utóbbi évek rohamos technológiai fejlődése a molekuláris biológiai vizsgálómódszerek területén lehetővé tette, hogy a daganatos betegségekhez társuló genetikai rendellenességek kimutatása a hagyományos egy eltérés-egy gén léptékről géncsoportokra vagy akár a teljes genomra helyeződjenek át. Daganatos betegségekben e vizsgálatoknak óriási a jelentősége. Számos olyan kórforma ismert, amelyben a daganatok családon belüli halmozódása figyelhető meg, illetve számos olyan eltérés vált ismertté, amely speciális terápia indikálását vonja maga után. Bár a mintaforrás és minta-előkészítés alapvetően eltérő a csírasejtes és szomatikus eltérések vizsgálatakor, a technológiai háttér ugyanaz. A klinikai genetikai munka során a vizsgálatok célja azon betegek azonosítása, akikben egy adott csírasejtes eltérés hordozása daganatos kórkép nagy kockázatával jár együtt, míg kialakult daganat esetében a daganatszövet genetikai vizsgálatával kimutathatók azok a génhibák, amelyek terápiás beavatkozások célja lehet. Jelen rövid összefoglalóban a szerzők áttekintik az új generációs szekvenálás nyújtotta lehetőségeket a hormonális rendszer daganatainak genetikai kivizsgálásában, kitérve a szakmai ajánlásokra, a vizsgálatok során felmerülő technikai és etikai kérdésekre. Orv. Hetil., 2015, 156(51), 2063-2069.
\end{abstract}

Kulcsszavak: phaeochromocytoma, paraganglioma, mutáció, új generációs szekvenálás

\section{Novel methods and their applicability in the evaluation of genetical background of tumours of the endocrine system}

The technical developments leading to revolution in clinical genetic testing offer new approaches for patients with cancer. From one mutation or one gene approach the scale of genetic testing moved to whole exome or whole genome scale. It is well known that many tumours are genetically determined ans they are part of familial tumour syndromes. In addition, some mutations indicate specific molecular targeted therapies. Although sampling and sample preparation are different for testing germline and somatic mutations, the technical background of the analysis is the same. The aim of clinical genetic testing is to identify patients who are carriers of disease-causing mutations or to test tumour tissue for the presence of genetic alterations which may be targets for therapeutic approaches. In this review the authors summarize novel possibilities offered by next-generation sequencing in clinical genetic testing of patients with endocrine tumours. In addition, the authors review recent guidelines on technical and ethical issues related to these novel methods.

Keywords: pheochromocytoma, paraganglioma, mutation, next-generation sequencing

Patócs, A., Likó, I., Butz, H., Baghy, K., Racz, K. [Novel methods and their applicability in the evaluation of genetical background of tumours of the endocrine system]. Orv. Hetil., 2015, 156(51), 2063-2069.

(Beérkezett: 2015. október 5.; elfogadva: 2015. október 29.) 


\section{Rövidítések}

$\mathrm{Gb}=$ gigabázis; $\mathrm{MEN}=$ multiplex endokrin neoplasia $; \mathrm{MB}=$ megabázis; NFl = neurofibromatosis 1 -es típusa; NFI = neurofibromatosis l-es típusáért felelős gén; $\mathrm{NGS}=$ új generációs szekvenálás; $\mathrm{PCR}=$ polimeráz láncreakció; $P R K A R I A=$ cAMP-függő fehérjekináz-l $\alpha$-alegységét szabályozó gén; PTPNII = nem receptor típusú fehérjetirozin-foszfatáz-l1-et kódoló gén; $R E T$ = rearrenged during transfection gén; SDHA = szukcinát-dehidrogenáz alfa-alegységet kódoló gén; SDHAF2 = szukcinát-dehidrogenáz-komplexhez asszociált fehérje; $S D H B=$ szukcinát-dehidrogenáz $\mathrm{B}$ alegységet kódoló gén; $S D H C$ = szukcinát-dehidrogenáz $\mathrm{C}$ alegységet kódoló gén; $S D H D=$ szukcinát-dehidrogenáz $\mathrm{D}$ alegységet kódoló gén; TMEM127 = transzmembrán protein 127 ; VHL = von Hippel-Lindau-szindróma

A molekuláris genetikai módszerek rohamos fejlődése és terjedése a klinikai genetikai diagnosztika átalakulásához vezet. Korábban a genetikai vizsgálatok során a monogénes kórképek esetében általában egy gén vagy a leggyakoribb mutációk vizsgálatát végezték el polimeráz láncreakciót (PCR) követő bidirekcionális Sanger-szekvenálással. Azonban már korábban is ismert volt, hogy számos esetben (akár örökletes daganatos betegségekben is) több gén hibája állhat a daganatos betegség hátterében [1]. Az emlö- vagy vastagbélrák hátterében is több különböző gén patogenetikai szerepét igazolták, így a diagnosztikus genetikai vizsgálatoknak ezeknek a géneknek a vizsgálatára is ki kell terjedniük. A hagyományos módszerekkel ezek a vizsgálatok hatalmas költséget jelentenek, és a mintavételtől az eredmény kiadásáig eltelt idő nagyon gyakran több hónapnál hosszabb.

A hormonális rendszer daganatai közül számos tumor társul úgynevezett monogénes tumorszindrómákhoz (1. táblázat). Ezeknek a szindrómáknak nagyon eltérő a klinikai megjelenése; számos daganat, mint például a mellékpajzsmirigy jóindulatú tumora vagy a mellékvesevelőből kiinduló phaeochromocytoma, több szindróma részjelensége lehet $[2,3,4]$. Ezeknek a szindrómáknak a másik fontos tulajdonsága az, hogy még ugyanazt a mutációt hordozó családokban is nagyon eltérő a daganatok penetranciája. Ezek a jellegzetességek hozzájárulnak ahhoz, hogy a klinikai diagnózis felállítása gyakran nehéz, és még sporadikusnak tûnő esetekben is gondolni kell örökletes betegségre.

A leggyakrabban felismert és vizsgált endokrin tumorszindrómák a multiplex endokrin neoplasia l-es (MEN-1) és 2-es típusa (MEN-2), von Hippel-Lindauszindróma, neurofibromatosis 1-es típusa, örökletes phaeochromocytoma/paraganglioma szindrómák, Cowden-kór és a Carney-komplex. Közös jellemzőjük az autoszomális domináns öröklésmenet, ami az utódokban 50\%-os valószínüséggel vezet a betegséget okozó eltérés transzmissziójához [4].
1. táblázat A hormonális rendszer daganataival társuló örökletes tumorszindrómák klinikai jellemzői

\begin{tabular}{lll}
\hline & $\begin{array}{l}\text { Daganatok és egyéb } \\
\text { eltérések }\end{array}$ & $\begin{array}{l}\text { Betegséget okozó } \\
\text { gén }\end{array}$ \\
\hline $\begin{array}{l}\text { Multiplex endokrin } \\
\text { neoplasia }\end{array}$ & $\begin{array}{l}\text { Mellékpajzsmirigy- } \\
\text { adenoma }\end{array}$ & $M E N-1$ \\
1-es típus & $\begin{array}{l}\text { Hypophysisdaganat } \\
\text { Enteropancreaticus } \\
\text { neuroendokrin daganat } \\
\text { Multiplex endokrin }\end{array}$ & \\
neoplasia & $\begin{array}{l}\text { Phaeochromocytoma } \\
\text { Mellékpajzsmirigy- }\end{array}$ & \\
2-es típus & RET & \\
&
\end{tabular}

adenoma

Von Hippel- Haemangioblastoma

Lindau-szindróma Világos sejtes veserák

Phaeochromocytoma

Pancreas szigetsejtes

daganat

Vese- és pancreasciszták

\begin{tabular}{|c|c|c|}
\hline $\begin{array}{l}\text { Paraganglioma/ } \\
\text { Phaeochro- } \\
\text { mocytoma }\end{array}$ & $\begin{array}{l}\text { Phaeochromocytoma } \\
\text { Fej-nyak paraganglioma }\end{array}$ & $\begin{array}{l}\text { SDHA, SDHAF2, } \\
\text { SDHB, SDHC, } \\
\text { SDHD, FH, MAX, } \\
\text { TMEM127 }\end{array}$ \\
\hline $\begin{array}{l}\text { Neurofibromatosis } \\
\text { l-es típusa }\end{array}$ & $\begin{array}{l}\text { Neurofibromák } \\
\text { (bőr és bél) } \\
\text { Café-au-lait foltok } \\
\text { Neurofibromák } \\
\text { Lisch-csomók } \\
\text { (iris neurofibroma) } \\
\text { Opticus glioma, } \\
\text { Központi idegrendszeri } \\
\text { daganatok } \\
\text { Phaeochromocytoma }\end{array}$ & $N F 1$ \\
\hline Tuberosus sclerosis & $\begin{array}{l}\text { Angiomyolipoma } \\
\text { Hypopigmentált maculák } \\
\text { Veseciszták } \\
\text { Hamartomák } \\
\text { Ritkán } \\
\text { phaeochromocytoma }\end{array}$ & TSC1, TSC2 \\
\hline Carney-komplex & $\begin{array}{l}\text { Primer pigmentált } \\
\text { nodularis } \\
\text { mellékvesekéreg- } \\
\text { hyperplasia, } \\
\text { Szív- és bőrmyxomák, } \\
\text { acromegalia } \\
\text { Emlö- és heredaganatok }\end{array}$ & PRKARIA \\
\hline $\begin{array}{l}\text { Li-Fraumeni- } \\
\text { szindróma }\end{array}$ & $\begin{array}{l}\text { Mellékvesekéreg- } \\
\text { carcinoma, Emlő- és } \\
\text { heredaganatok, } \\
\text { csonttumorok, sarcoma, } \\
\text { agydaganat }\end{array}$ & TP53 \\
\hline $\begin{array}{l}\text { Cowden/BRR- } \\
\text { szindróma }\end{array}$ & $\begin{array}{l}\text { Fibrocystás emlőbetegség } \\
\text { Lipomatosis } \\
\text { Follicularis pajzsmirigy- } \\
\text { carcinoma } \\
\text { Endometrium carcinoma } \\
\text { Trichilemmoma }\end{array}$ & PTEN \\
\hline
\end{tabular}

BRR-szindróma: Bannayan-Riley-Ruvalcaba-szindróma; LKBI/ STK11: szerin, treonin-kináz 11-et kódoló gén; NF1: neurofibromatosis 1 -es típusáért felelős gén; PRKAR $1 A$ : cAMP-függő fehérjekináz-1 ๙-alegységét szabályozó gén; PTPNI1: 11 -es nem receptor típusú fehérje-tirozin-foszfatázt kódoló gén; $S D H$ : szukcinát-dehidrogenáz alegységeit kódoló gének; TP53: p53 tumorszuppresszor gén; TSC1, TSC2: hamartint és tuberint kódoló gének; VHL: von Hippel-Lindaubetegség 


\section{Örökletes endokrin tumorszindrómák}

A MEN-1 szindróma fó komponensei a mellékpajzsmirigy-adenoma vagy -hyperplasia, hasnyálmirigy neuroendokrin daganat és hypophysisdaganat. A betegséget a $M E N-1$ tumorszuppresszor gén örökletes mutációi okozzák. A betegségokozó génhibák lehetnek pontmutációk, deletiók és inszerciók, amelyek a gén teljes szakaszán előfordulhatnak. Specifikus genotípus-fenotípus összefüggés nem ismert.

A MEN-1 szindróma egyik fö összetevője, a mellékpajzsmirigy-adenoma egyéb örökletes szindrómákban is előfordulhat (MEN-2 szindróma, familiáris hypercalcaemiás hypocalciuria $[\mathrm{FHH}]$, familiáris izolált hyperparathyreosis [FIHPT], mellékpajzsmirigy-adenoma-állkapocstumor szindróma). Ezek a kórképek szintén autoszomális domináns öröklődésmenetet követnek. Ezért mellékpajzsmirigy-adenoma esetén több gén vizsgálata is indokolt lehet (MEN-2 szindróma gyanúja esetén RET, FHH és FHIP gyanúja esetén CaSR és mellékpajzsmirigy-adenoma-állkapocstumor szindróma gyanúja esetén HPRT2 gén vizsgálat) [4].

MEN-2 szindrómában medullaris pajzsmirigyrák, phaeochromocytoma és hyperparathyreosis fordul elő. A klinikai megjelenés alapján több klinikai altípus ismert. Ezek közül kiemelendő a rendkívül súlyos lefolyást mutató $M E N-2 B$ szindróma, amelyben a fent ismertetett tumorokhoz jellegzetes külső jelek (marfanoid alkat, ajak-, száj- és szemhéjnyálkahártya-neuromák) társulnak. A betegségért a $R E T$ protoonkogén aktiváló mutációi a felelősek. Ebben a kórképben a RET protoonkogén-mutációk igazolásának nemcsak a diagnózis felállításában, hanem a betegség prognózisának a megítélésében is fontos szerepe van. Szoros genotípus-fenotípus összefüggések ismertek, amelyek meghatározzák a mutációt hordozókban a preventív pajzsmirigy-eltávolítás időpontját. Látszólag sporadikus medullaris pajzsmirigyrákos esetek 1-7\%-ában mutatható ki RET-mutáció [4].

A MEN-2 szindróma különösen fontos komponense a phaeochromocytoma. A phaeochromocytoma hátterében napjainkig nem kevesebb, mint 15 gén csírasejtes mutációját igazolták (2. táblázat). Örökletes phaeochromocytoma/paraganglioma szindrómában a szukcinátdehidrogenáz enzim (SDH) alegységeit kódoló gének (SDHA, SDHB, SDHC, SDHD, SDHAF2) mellett az elmúlt néhány évben azonosított gének (FH, KIFlB, PHD2, MAX, TMEM127 és MDH2) is szerepet játszanak. A klinikai gyakorlatban phaeochromocytoma, illetve paraganglioma esetén a leggyakrabban a $R E T, V H L$, $S D H B$ és $S D H D$ gének vizsgálatát végzik $[1,5,6,7,8$, $9,10,11,12,13,14,15,16]$, de indokolt esetben a többi gén vizsgálata is szükséges lehet. A diagnózis megállapítását természetesen az egyes szindrómák klinikai és biokémiai jellegzetességei is segíthetik. A génspecifikus molekuláris genetikai vizsgálatok mellett foglalt állást az Amerikai Endokrin Társaság és ajánlásában fenotípusorientált algoritmus alkalmazására tett javaslatot [2]. Az
2. táblázat | Phaeochromocytomák és paragangliomák hátterében álló örökletes genetikai eltérések és felfedezésük ideje

\begin{tabular}{lll}
\hline Szindróma & Gén & $\begin{array}{l}\text { Azonosításának } \\
\text { ideje }\end{array}$ \\
\hline Neurofibromatosis 1-es típus & NF1 & 1990 \\
von Hippel-Lindau-szindróma & $V H L$ & 1993 \\
MEN-2 & $R E T$ & 1994 \\
PGL1 & SDHD & 2000 \\
PGL4 & SDHB & 2000 \\
PGL3 & SDHC & 2001 \\
Pheo-, neuroblastoma, & KIF1ß & 2008 \\
tüdőcarcinoma & & \\
Paraganglioma, erythrocytosis & PHD2 & 2008 \\
PGL2 & SDHAF2 & 2010 \\
Pheo-, paraganglioma & TMEM127 & 2010 \\
Pheo-, paraganglioma & SDHA & 2011 \\
Pheo-, paraganglioma & $M A X$ & 2011 \\
Pheoganglioma & $F H$ & 2014 \\
Pheoganglioma & MDH2 & 2015 \\
\hline
\end{tabular}

ajánlás szerint MEN-2 és a VHL-szindróma kizárását követôen a szukcinát-dehidrogenáz enzim alegységeit kódoló $S D H B, S D H C$ és $S D H D$ gének csírasejtes mutációinak vizsgálata javasolt. SDH génmutációk a látszólag sporadikus esetek 10-15\%-ában is előfordulhatnak. Az $S D H B, S D H C$ és $S D H D$ gének egyidejü vizsgálata célszerú, de a fenotípus alapján prioritás is megállapítható. Így például fontos megfigyelés, hogy $S D H C$-mutációt mind ez idáig csak fej/nyak paragangliomák esetében igazoltak. Malignitás gyanúja esetén elsőként az $S D H B$ gén vizsgálata javasolt [2].

A következókben a phaeochromocytoma/paraganglioma szindrómát okozó 15 gén egyidejű vizsgálatára alkalmas új generációs szekvenálási eljárást mutatjuk be és elemezzük ennek előnyeit, illetve hátrányait.

\section{Az új generációs szekvenálási technológia háttere}

Az új generációs szekvenálási technikák (next-generation sequencing - NGS) közös jellemzője, hogy egy mérés során lehetőség van több ezer (millió) különböző DNSminta párhuzamos vizsgálatára, ami nagy áteresztőképességet (bigh-throughput) jelent. Felhasználási területe rendkívül szerteágazó, az alapkutatásoktól egészen a rutindiagnosztikáig terjed [17]. Az elvárások azonban közösek, és teljesítésük csak több szakterület (laboratóriumi szakorvos, informatikus, biológus) együttes munkája esetén lehet sikeres.

\section{Minta-elōkészités és könyvtárkészités}

Az NGS-alapú mérés kiindulási anyaga itt sem más, mint a hagyományos molekuláris biológiai módszerek esetén: 
jó minőségű és elegendő mennyiségű nukleinsavra van szükség. A kiindulási DNS-nek épnek és töredezéstől mentesnek kell lennie. Ez annak ellenére feltétel, hogy az NGS-mérések kezdeti lépésében végzendő könyvtárkészítés során a DNS porlasztását végzik annak érdekében, hogy a platformfüggő adapterszekvenciák bekötése (ligálása) megtörténjen. Platformtól függően a következő lépés az adapterszekvenciákkal kiegészített DNS-molekulák sokszorozása. Ez történhet PCR-rel vagy hibridizációval [17]. A Life Technologies/Thermo Fisher (Carlsbad, CA, Amerikai Egyesült Államok) platform esetén a SOLID, PGM és Ion Proton rendszerek alkalmazásakor még egy köztes lépésre, az úgynevezett nick transzlációra is szükség van [18]. Mindezek miatt nem kerülhetők el teljes mértékben a célszekvenciákból eredő hibák (PCR-primerek eltérő affinitása a különböző szekvenciákhoz, magas GC-tartalom, hosszú repetitív szekvenciák). Szintén problémát jelenthetnek a genom kópiaszám-változásokat mutató régiói, valamint a célgénekkel nagyfokú homológiát mutató pszeudogének jelenléte. Ezek biztos vizsgálata úgynevezett áthidaló PCR-termékek szekvenálásával lehetséges.

Amplikonszekvenálás esetén a könyvtárkészítés során a célszekvenciákra specifikus primereket és próbákat terveznek. A könyvtár nagyságát a szekvenáláshoz rendelkezésre álló eszköz határozza meg. Jelenleg a génpanelek átlagosan 8-160 génig terjednek, attól függően, hogy melyik gyártó készülékén történik a mérés. A lefedettség, így a célgénszakaszokról származó információ nagy, akár többezres lefedettség is elérhető, főleg kisebb panelek esetében. Ugyanakkor a PCR során felmerül a duplikáció lehetősége, amikor a PCR-rel létrehozott duplikátumok nem különíthetők el az eredeti célszekvencia amplifikálásától [17]. Hátrányt jelent az is, hogy azokról a génekról kapunk csak információt, amelyek a panelünkben szerepelnek. Ezért például olyan betegségek esetében, amelyeknél új gének szerepe merül fel, új panelek tervezése szükséges.

\section{NGS-en alapuló szekvenálás alapelvei és gyakorlati jellemzöi}

Jelen összefoglaló terjedelmi korlátai nem teszik lehetővé, hogy részletesen ismertessük az összes forgalomban levő, NGS-t alkalmazó technológiát, ezért csak a klinikai diagnosztikában már kipróbált módszereket mutatjuk be.

\section{Illumina szekvenálás}

A könyvtárkészítés alapja a kiindulási DNS darabolása/ fragmentálása, amihez egy timinel túlnyúló véggel rendelkező adapter DNS-t ligálnak. A ligált DNS-t egyszálúsítják a mintát egy szekvenáló cellába (flow cell) viszik fel. A mérés és a gyártó készülékeinek kapacitását az is meghatározza, hogy hány ilyen cellát tartalmaznak. A fóbb készülékek közül a miSeq egyet, a HiSeq2500 és a 2014-től elérhető NextSeq500 és a HiSeq X Ten kettőt tartalmaznak. Ez utóbbi készülék a legnagyobb kapacitá- sú, elsődleges felhasználási területe a populációs szintű genomikai vizsgálatok végzése és mind közepes (40 Gb kimenő adat) mind nagy teljesítmény (120 Gb kimenő adat) elérésére képes. Ennek a készüléknek a nem titkolt célja az, hogy egy humán genom szekvenálása 1000 USD alá kerüljön. Az Illumina készülékek múködési alapja az adapterrel komplementer primerek, és ezek felhasználása az úgynevezett híd-amplifikáció (bridge amplification) során. Maga a szekvenálás szintézissel történik, a templáthoz egy primert ligálnak, majd a reakcióhoz egyszerre adják hozzá a 4 különböző fluoreszcens jelölt nukleotidokat. A szekvenálás során beépült nukleotidok jelét CCD kamerával vagy LED alapon detektálják [19, 20].

\section{Life Technologies/Thermo Fisher PGM és Ion Pro- ton szekvenálás}

A módszer félvezető technológiát használ és a beépülő nukleotidok során felszabaduló protonokat detektálja [18]. A szekvenálandó templátokat gyöngyökön készítik el emulziós PCR segítségével. Ebben a víz-olaj keverékben a szekvenáláshoz szükséges összes reagens jelen van. A templátként szolgáló gyöngyöket a protont érzékelő lyukakba töltik, majd a szekvenálási reakció során a beépülő nukleotidokkal arányos mennyiségú protonfelszabadulás jön létre, amit a beépített ph-szenzor detektál [19]. Az Illumina és Ion Torrent jelfeldolgozásában a hibák aránya hasonló, körülbelül $0,1 \%$, bár 3,5\%-ot is elérhet azoknál a templátoknál, ahol homopolimerek fordulnak elő. Ezek tipikusan a sok adenint tartalmazó szekvenciák [21].

\section{Roche 454 szekvenálás}

Kifejezetten a klinikai genetikai diagnosztikai alkalmazást tartotta szem előtt a Roche, amikor bevezette a piroszekvenáláson alapuló technológiáját. A korábban ismertetett eljárásokhoz képest abban is előrelépést jelentett, hogy a GS Junior elnevezésű készülék kisebb léptékű, egyedileg tervezett génlisták szekvenálását is lehetővé tette. Hasonlóan az Illuminához, a szekvenálás szintézissel történik egy speciális, mikrotiter platen, amelyben a lyukátmérő olyan, hogy abba egyszerre csak egy gyöngy fér be. Ezeken a gyöngyökön mennek végbe a szekvenálási reakciók, amelyek során a polimeráz meghosszabbítja a DNSszálat a platekhez ciklikusan hozzáadott fluoreszcens jelet kibocsátó nukleotidokkal. A beépítés során fotonemiszszió jön létre, amit CCD-kamerával detektálnak [22].

Érdekességként jegyezzük meg, hogy klinikai alkalmazás során az első genetikai diagnózishoz, amit teljes humán exom szekvenálásával állítottak fel, hibrid módszert (a könyvtárkészítéshez a Nimblegen/Roche reagenst, míg a szekvenáláshoz Illumina készüléket) használtak [23]. Ez előrevetítette azt a lehetőséget, hogy bár minden gyártó igyekszik saját termékpalettáját kialakítani, a könyvtárkészítéshez vagy a célzott szekvenáláshoz szükséges primerek tervezése során egyéni megoldások és ezek ötvözése is elképzelhető. 


\section{Adatok értékelése, bioinformatika}

Sikeres szekvenálást követôen az adatok elemzése jelenti a valódi kihívást, hiszen a módszertól függően akár 100 Gb méretû́ adatállomány kezelése és értelmezése szükséges. Természetesen minden gyártónak van saját adatértékelő programcsomagja, és a terület dinamikus fejlődése révén számos ingyenesen elérhetó algoritmus is rendelkezésre áll. Ahhoz, hogy a napi klinikai genetikai diagnosztikában elterjedjen az NGS-alapú metodikák használata, a bioinformatikai munkafolyamatok klinikai validálása is szükséges. Ezt fogalmazta meg az Európai Humángenetikai Társaság ajánlása is, ami kimondja, hogy a bioinformatikai elemzés eredményének értékelése a klinikai genetikus, humángenetikus, laboratóriumi szakember és az adott betegségben jártas klinikus orvos közös feladata [24].

A feldolgozás során első lépés az adatok minőségének elemzése, majd a könyvtárkészítés során használt adapterszekvenciák levágása. Ezt követi a megmaradt szekvenciák referenciagenomra történő illesztése. Célzott szekvenálás során a referenciagenomból a célgének koordinátáit veszik alapul, míg exom vagy teljes genom szekvenálásakor a teljes genomot. Az illesztéshez komoly számítástechnikai háttér szükséges (adatok tárolása, az illesztések során átmeneti tárolás és számítókapacitás).

A szekvenciák illesztését követően minden egyes bázishoz megkapjuk azt, hogy valójában hány olvasatban (readben) van jelen az adott mérésben, ezt hívjuk lefedettségnek (covarage). Az irodalomban még nem alakult ki konszenzus annak eldöntésére, hogy mekkora az a minimális lefedettség, ami szükséges egy szekvenálási eredmény elfogadásához. Csírasejtes DNS szekvenálásakor általában minimum 10-15 readet tekintenek elfogadhatónak. Heterozigóta mutációk/variánsok esetében feltétel az is, hogy a két allél közötti readmegoszlás az ideális 50-50\%-tól csak akkor fogadható el, ha a kevésbé lefedett allél esetén is minimum $20 \%$-os előfordulás volt kimutatható [18].

A szekvenálási readek illesztése után a következő feladat azoknak az eltéréseknek a meghatározása, amelyeknek potenciális szerepe lehet a betegség kialakulásában. Számos integrált algoritmussal, mint például a Genome Analyser Tool Kittel (GATK) direkt kapcsolat létesíthető azokhoz az adatbázisokhoz, amelyekből a referenciagenomok allélmegoszlási adatait elérhetjük, illetve in silico funkcióelemzéseket is végezhetünk [25]. A bioinformatikusok szerepe ezekben a lépésekben elengedhetetlen. Mindezek után egy olyan adatbázist kapunk, amely tartalmazza az összes beazonosított variánst és a hozzájuk tartozó adatokat. Ezeket variant calling fájloknak (vcf) hívjuk.

A klinikai genetikus munkája igazából itt kezdődik. Az azonosított eltérések klinikai interpretációjában figyelembe kell venni az adott eltérés allélgyakoriságát, funkcionális következményét, valamint a különböző mutációs adatbázisokban (dbSNP, clinVar, HMGD, OMIM) tárolt információkat. Ismert gének esetében ez egyszerú szűrésekkel viszonylag könnyen kivitelezhető. A következőkben phaeochromocytoma/paraganglioma szindrómákban az NGS-alapú vizsgálatokkal nyert eredményeket foglaljuk össze.

\section{A phaeochromocytoma/paraganglioma szindrómák klinikai genetikai diagnosztikája NGS-módszerekkel}

\section{Amplikonszekvenálás}

Mind ez idáig három tanulmányban vizsgálták a phaeochromocytoma/paraganglioma szindrómák hátterében álló géneket génpanelekkel. Rattenberry és mtsai amplikonszekvenálást végeztek GS Junior készülékkel. Öszszesen 9 gén egyidejű vizsgálatára terveztek amplifikációt [26]. Welander és mtsai 14 gén vizsgálatát végezték el Illumina MiSeq platformon [27]. Ezek a tanulmányok elsősorban az NGS metodikai alkalmazhatóságát kívánták igazolni. A GS Juniorral végzett analízis a 77 ismert variánsból mindösszesen egyet nem talált meg, a módszer szenzitivitása $98,7 \%$ volt. A második tanulmány fó eredménye az volt, hogy a bioinformatikai elemzés és az alkalmazott szúrések alapján a szenzitivitás 82,9-100\% között változott. A specificitás mindkét módszer esetében elmaradt a jelenlegi rutin laboratóriumi diagnosztikában használt mérőmódszerekétől. A GS Junior-mérés során a 164 beazonosított eltérés közül 46 álpozitív volt, ami elsősorban a homopolimer hibájára volt visszavezethető. A szerzők ugyanakkor hangsúlyozták, hogy az elemzésben alkalmazott szúrésekkel ezek száma jelentô" sen csökkenthető [26]. A MiSeq készülékkel a módszer specificitása $>99 \%$ volt, egyértelmúen jelezve a módszer alkalmazhatóságát [27].

Ezeknek az eredményeknek a megerősítésére Crona és mtsai ebben az évben publikált tanulmányukban a bioinformatikai algoritmusokat elemezték [28]. A MiSeq készülékhez fejlesztett MiSeq Reporter beazonosította az összes eltérést, de mintánként mintegy 100 álpozitív eltérés is előfordult. A CLC Genomics workbench elnevezésú programcsomag 8-11 álnegatív eredményt közölt (szenzitivitás: 76,9-85,1\%). A szerzők által kifejlesztett saját algoritmus teljesítóképessége a két módszer között helyezkedett el [28]. Mindezek az eredmények óvatosságra intenek; az NGS-alapú mérések eredményeinek a klinikai döntéshozatalba történő integrálása előtt érdemes több bioinformatikai elemzést elvégezni, illetve hagyományos molekuláris biológiai módszerekkel kell az eredményeket megerősíteni.

\section{Exomszekvenálás eredményei phaeochromocytoma/paraganglioma szindrómás betegekben}

Az exomszekvenálás jelentőségét phaeochromocytoma/ paraganglioma szindrómás betegek genetikai vizsgálatá- 
ban jól mutatja, hogy mind a $M A X$, mind az $M D H 2$ géneket ezzel a módszerrel fedezték fel. Ezek az eredmények kutatási projektek révén születtek, ahol olyan betegeket vizsgáltak, akik az addig ismert génekben nem hordoztak eltéréseket. Az exomszekvenálás során olyan génhibákat kerestek, amelyek a betegekben heterozigóta formában voltak jelen, nem szerepeltek korábbi genetikai adatbázisokban és szegregálódtak a betegséggel. A daganatszövetek genetikai vizsgálata alátámasztotta az autoszomális dominás öröklésmenetet, és megállapították, hogy mind a $M A X$, mind az $M D H 2$ klasszikus tumorszuppresszor gének $[14,16]$.

A fenti eredmények azonban nem feltétlenül jelentik azt, hogy új gének kimutatására az exomszekvenálás lenne a választandó genetikai vizsgálómódszer. Amint a célzott amplikonszekvenálások esetében említettük, a módszer szenzitivitása és specificitása nem éri el a 100\%-ot. Jelenleg az exomszekvenálás a klinikai genetikai diagnosztikában mint szűrőmódszer terjedt el. A vizsgálatok során elsősorban azokat a géneket elemzik, amelyek patogenetikai szerepe már bizonyított (ilyenek a jól ismert onkogének, illetve a phaeochromocytoma/paraganglioma szindrómákkal összefüggő gének). A módszerrel természetesen egyéb monogénes kórképek esetében is könnyen szűrhetőek és elemezhetők az adott génről származó adatok. Mindezzel együtt jelenleg nem ismert olyan komplex vizsgálat, amely egyértelmüen vizsgálta volna az exomszekvenálás teljesítőképességét a rutindiagnosztika során. Az eredményeket befolyásolja a könyvtárkészítés módja és a bioinformatikai adatfeldolgozás. $\mathrm{Az}$ ismert gének lekérdezése után átlagosan több száz vagy akár ezer olyan variáns is maradhat, amelyek potenciálisan patogének (fehérjeszerkezetet kritikusan érintő mutációk) lehetnek. A valóban betegséget okozó eltérések tényleges patogenetikai szerepe csak genetikai asszociációs vizsgálatokkal bizonyítható.

További kritikus elem a korábban is említett kópiaszám-változást mutató régiók és a pszeudogének kérdése. Saját tapasztalatunk alapján például a CYP21A2 gén (a 21-hidroxiláz-defektus kialakulásáért felelős gén) esetében több mint 20 minta két különböző platformon végzett exomszekvenálása nem talált egyetlen eltérést sem, holott Sanger-szekvenálással számos gyakori polimorfizmus volt kimutatható. Jelenleg a legtöbb klinikai genetikai intézet az exomszekvenálást komplex elővizsgálatként használja és testreszabott algoritmusokkal az adott betegséggel összefüggésbe hozott géneket elemzi $[24,29]$.

\section{Etikai kérdések}

A technológiai kérdések mellett fontos kitérnünk a vizsgálat során felmerülő etikai kérdésekre is. Jelenleg a vizsgálatba történő beleegyező nyilatkozatban a vizsgált egyén genetikai tanácsadást követően nyilatkozik arról, hogy milyen vizsgálatba egyezett bele és milyen felvilágosításra tart igényt. A jelenlegi ajánlás szerint a diag- nosztikai célból végzett vizsgálatok esetén az eredmények közül a betegségével összefüggő géneltérésekről kaphat tájékoztatást egy újabb genetikai tanácsadás során. Az NGS-alapú technológiák szükségessé teszik új típusú beleegyező nyilatkozat használatát. Ebben ki kell térni a vizsgálat módjára, az adatok elemzésére, tárolására, a közölhető eredményekre és az incidentális eltérések kezelésére. Az incidentálisan felfedezett eltéréseknek jelenleg másodlagos szerepe van, általában nem kerülnek az eredményt közlő dokumentumba. A kérdés rendkívüli fontosságára hívja fel a figyelmet Vrijenboek és mtsai 2015-ben publikált tanulmánya [29]. Hypertrophiás cardiomyopathia genetikai hátterének vizsgálata során 8 genetikai központ NGS-alapú vizsgálati stratégiáját hasonlították össze. Elsődleges céljuk nem a módszerek technikai összehasonlítása volt, hanem a kiadott genetikai vizsgálati eredmények közötti egyezőség/különbözőség feltárása. A 8 központ eltért a vizsgálómódszerekben, mind a technológiai, mind az adatértékelésben. A 8 központból kettőben nem igazolták a betegség kialakulásáért felelős eltérést, helyette az egyik központban a Fábry-kór diagnózisát állapították meg, míg a másik központ negatív eredményt adott ki. Az a központ, amely negatív eredményt kapott, hagyományos Sangerszekvenálással igazolta a patogénhibát, megerósítve azt a stratégiát, hogy a klinikai diagnosztikában a Sanger-szekvenálással is megerősített eredmény elfogadható. A tanulmány összehasonlította a beleegyező nyilatkozatok tartalmát is; a 8 közül 3 központban a használt nyilatkozat nem tartalmazta a vizsgálat célját (kutatási vagy diagnosztikai cél), illetve, hogy hogyan kezeljék a másodlagos eredményeket (szorosan a betegséggel nem összefüggő gének eltéréseit). A szerzők, összhangban az Európai Humángenetikai Társaság ajánlásával, multidiszciplináris team összehívását javasolják, amelyben klinikai genetikus, laboratóriumi szakember, klinikus és bioinformatikus együttesen alakítja ki a vizsgálati stratégiát, a beleegyező nyilatkozat tartalmát és azokat a minőségi standardokat, amelyek szükségesek az NGS technikai kivitelezéséhez, továbbá a validálás mikéntjét és az eredményközlés tartalmát.

\section{Következtetések}

Az NGS-alapú vizsgálómódszerek rohamosan fejlődnek és a klinikai genetikai diagnosztikában is terjednek. A technológiai fejlesztések révén a vizsgálatok ára kedvező, ami rendkívül csábító. Számos kereskedelmi szolgáltató kínál első hallásra kedvező árú vizsgálatokat, amelyek felhasználása a klinikai döntéshozatalban csak az eredmények validálását követően fogadható el. Feladatunk a tájékoztatás, a figyelem felhívása, hogy a klinikai diagnosztikában csak az olyan módszer megengedett, amely technikailag validált és teljesítőképessége bizonyított. Iránymutatónak kell tekinteni az orvosszakmai társaságok óvatosságra intő szakmai ajánlásait. 
Anyagi támogatás: A közlemény elkészítése a Bionikai Innovációs Központ kutatási támogatásával valósult meg.

Szerzői munkamegosztás: P. A.: Témaválasztás, adatok elemzése, kézirat megírása. L. I., B. H., B. K.: Adatok gyưjtése, elemzése, összehasonlítások elkészítése, kézirat véleményezése, javítása. R. K.: A kézirat kritikai észrevételezése, javítása. A cikk végleges változatát valamennyi szerző elolvasta és jóváhagyta.

Érdekeltségek: A szerzóknek nincsenek érdekeltségeik.

\section{Köszönetnyilvánítás}

A szerzők köszönetüket fejezik ki a Bionikai Innovációs Központ kutatási támogatásáért. Patócs Attila az MTA „Lendület” pályázat nyertese.

\section{Irodalom}

[1] Toledo, R. A., Dabia, P. L.: Next-generation sequencing for the diagnosis of hereditary pheochromocytoma and paraganglioma syndromes. Curr. Opin. Endocrinol. Diabetes Obes., 2015, $22(3), 169-179$.

[2] Lenders, J. W., Duh, Q. Ү., Eisenhofer, G., et al.: Pheochromocytoma and paraganglioma: an Endocrine Society Clinical Practice Guideline. J. Clin. Endocrinol. Metab., 2014, 99(6), 19151942.

[3] Karagiannis, A., Mikhailidis, D. P., Athyros, V. G., et al.: Pheochromocytoma: an update on genetics and management. Endocr. Relat. Cancer, 2007, 14(4), 935-956.

[4] Patócs, A.: Multiple endocrine neoplasias and other hereditary endocrine tumor syndromes. In: Leövey, A., Nagy, V. E., Paragh, G., et al. (eds.): Endocrine and metabolic disorders practical handbook. [Multiplex endokrin neoplasiák és egyéb örökletes endokrin tumor szindrómák. In: Leövey, A., Nagy, V. E., Paragh, G. et al. (szerk.): Az endokrin és anyagcsere-betegségek gyakorlati kézikönyve.] Medicina Könyvkiadó, Budapest, 2010. [Hungarian]

[5] Baysal, B. E., Ferrell, R. E., Willett-Brozick, J. E., et al.: Mutations in $S D H D$, a mitochondrial complex II gene, in hereditary paraganglioma. Science, 2000, 287(5454), 848-851.

[6] Niemann, S., Müller, U.: Mutations in SDHC cause autosomal dominant paraganglioma, type 3. Nat. Genet., 2000, 26(3), 268-270.

[7] Astuti, D., Latif, F., Dallol, A., et al.: Gene mutations in the succinate dehydrogenase subunit SDHB cause susceptibility to familial pheochromocytoma and to familial paraganglioma. Am. J. Hum. Genet., 2001, 69(1), 49-54.

[8] Hao, H. X., Khalimonchuk, O., Schraders, M., et al.: SDH5, a gene required for flavination of succinate dehydrogenase, is mutated in paraganglioma. Science, 2009, 325(5944), 1139-1142.

[9] Burnichon, N., Brière, J. J., Libé, R., et al.: SDHA is a tumor suppressor gene causing paraganglioma. Hum. Mol. Genet., 2010, 19(15), 3011-3020.

[10] Yeh, I. T., Lenci, R. E., Qin, Ү., et al.: A germline mutation of the KIFl $\beta$ gene on 1 p36 in a family with neural and nonneural tumors. Hum. Genet., 2008, 124(3), 279-285.

[11] Ladroue, C., Carcenac, R., Leporrier, M., et al.: PHD2 mutation and congenital erythrocytosis with paraganglioma. N. Engl. J. Med., 2008, 359(25), 2685-2692.
[12] Qin, Ү., Yao, L., King, E. E., et al.: Germline mutations in TMEM127 confer susceptibility to pheochromocytoma. Nat. Genet., 2010, 42(3), 229-233.

[13] Yao, L., Schiavi, F., Cascon, A., et al.: Spectrum and prevalence of FP/TMEM127 gene mutations in pheochromocytomas and paragangliomas. JAMA, 2010, 304(23), 2611-2619.

[14] Comino-Méndez, I., Gracia-Aznárez, F. J., Schiavi, F., et al.: Exome sequencing identifies MAX mutations as a cause of hereditary pheochromocytoma. Nat. Genet., 2011, 43(7), 663-667.

[15] Castro-Vega, L. J., Buffet, A., De Cubas, A. A., et al.: Germline mutations in $\mathrm{FH}$ confer predisposition to malignant pheochromocytomas and paragangliomas. Hum. Mol. Genet., 2014, 23(9), 2440-2446.

[16] Cascón, A., Comino-Méndez, I., Currás-Freixes, M., et al.: Wholeexome sequencing identifies $M D H 2$ as a new familial paraganglioma gene. J. Natl. Cancer Inst., 2015, 107(5), pii: djv053.

[17] Buermans, H. P., den Dunnen, J. T.: Next generation sequencing technology: Advances and applications. Biochim. Biophys. Acta, 2014, 1842(10), 1932-1941.

[18] Rothberg, J. M., Hinz, W., Rearick, T. M., et al.: An integrated semiconductor device enabling non-optical genome sequencing. Nature, 2011, 475(7356), 348-352.

[19] Bentley, D. R., Balasubramanian, S., Swerdlow, H. P., et al.: Accurate whole human genome sequencing using reversible terminator chemistry. Nature, 2008, 456(7218), 53-59.

[20] Merriman, B., Rothberg, J. M.: Progress in ion torrent semiconductor chip based sequencing. Electrophoresis, 2012, 33(23), 3397-3417.

[21] Quail, M. A., Smith, M., Coupland, P., et al.: A tale of three next generation sequencing platforms: comparison of Ion Torrent, Pacific Biosciences and Illumina MiSeq sequencers. BMC Genomics, 2012, 13, 341.

[22] Rothberg, J. M., Leamon, J. H.: The development and impact of 454 sequencing. Nat. Biotechnol., 2008, 26(10), 1117-1124.

[23] Choi, M., Scholl, U. I., Ji, W., et al.: Genetic diagnosis by whole exome capture and massively parallel DNA sequencing. Proc. Natl. Acad. Sci. U.S.A., 2009, 106(45), 19096-19110.

[24] Van El, C. G., Cornel, M. C., Borry, P., et al.: Whole-genome sequencing in health care: recommendations of the European Society of Human Genetics. Eur. J. Hum. Genet., 2013, 21(6), $580-584$.

[25] DePristo, M. A., Banks, E., Poplin, R., et al.: A framework for variation discovery and genotyping using next-generation DNA sequencing data. Nat. Genet., 2011, 43(5), 491-498.

[26] Rattenberry, E., Vialard, L., Yeung, A., et al.: A comprehensive next generation sequencing-based genetic testing strategy to improve diagnosis of inherited pheochromocytoma and paraganglioma. J. Clin. Endocrinol. Metab., 2013, 98(7), E1248E1256.

[27] Welander, J., Andreasson, A., Jublin, C. C., et al.: Rare germline mutations identified by targeted next-generation sequencing of susceptibility genes in pheochromocytoma and paraganglioma. J. Clin. Endocrinol. Metab., 2014, 99(7), E1352-E1360.

[28] Crona, J., Verdugo, A. D., Granberg, D., et al.: Next-generation sequencing in the clinical genetic screening of patients with pheochromocytoma and paraganglioma. Endocr. Connect., 2013, 2(2), 104-111.

[29] Vrijenhoek, T., Kraaijeveld, K., Elferink, M., et al.: Next-generation sequencing-based genome diagnostics across clinical genetics centers: implementation choices and their effects. Eur. J. Hum. Genet., 2015, 23(9), 1142-1150.

(Patócs Attila dr., Budapest, Szentkirályi u. 46., 1088 e-mail: patocs.attila@med.semmelweis-univ.hu) 